\title{
ANALISIS PERBANDINGAN KINERJA KEUANGAN BANK KONVENSIONAL DENGAN BANK SYARIAH PERIODE 2015-2019
}

\author{
Ila Komalasari ${ }^{1}$, Wirman $^{2)}$ \\ ${ }^{1,2)}$ Program Studi Akuntansi, Universitas Singaperbangsa Karawang \\ Email: ilakomalasari99@gmail.com
}

Diterima 7 Janauari 2021 / Disetujui 10 Agustus 2021

\begin{abstract}
Even though the majority of the population of Indonesia is Muslim, there is a lack of views about the advantages of Islamic banks, so they prefer to use conventional banking services. The target to be achieved is to find out whether there is a dissimilarity between conventional banks and Islamic banks in their financial performance. And to find out which banking institution is superior based on financial performance ratios. This study uses a comparative descriptive method through a quantitative approach. The sampling technique used is simple random sampling technique. The data used are financial ratios, namely CAR, NPL/NPF, ROA, BOPO, and LDR/FDR. Then the facts are as follows: 1) There is dissimilarity in CAR performance between the two banks, and CAR at conventional banks is superior to Islamic banks. 2) There is dissimilarity in the performance of NPL/NPF between the two banks, and the NPL/NPF of conventional banks is superior to that of Islamic banks. 3) There is no dissimilarity in ROA performance between the two banks, and ROA at conventional banks is superior to Islamic banks. 4) There is no dissimilarity in BOPO performance between the two banks, and BOPO at conventional banks is superior to Islamic banks. 5) There is no dissimilarity in the performance of LDR/FDR between the two banks, and LDR/FDR in Islamic banks is superior to conventional banks.
\end{abstract}

Keywords: Conventional Banks, Islamic Banks, Financial Performance, Financial Ratios

\begin{abstract}
ABSTRAK: Kendatipun sebagian besar penduduk negara Indonesia beragama Muslim, namun minimnya pandangan mengenai keunggulan bank syariah sehingga mereka lebih memilih memanfaatkan jasa perbankan konvensional. Sasaran yang ingin dicapai yakni ingin mendapati ada tidaknya dismilaritas bank konvensional dengan bank syariah dalam kinerja keuangannya, dan untuk mendapati lembaga perbankan mana yang lebih unggul beralaskan rasio kinerja keuangan. Penelitian ini memakai metode deskriptif komparatif melalui pendekatan kuantitatif. Dengan Teknik pengambilan sampel yang dipakai yakni teknik simple random sampling. Data yang dipakai berupa rasio-rasio keuangan yaitu CAR, NPL/NPF, ROA, BOPO, dan LDR/FDR. Kemudian faktanya yakni seperti berikut ini: 1) Adanya dismilaritas kinerja CAR antara kedua bank, dan CAR pada bank konvensional lebih unggul ketimbang bank syariah. 2) Adanya dismilaritas kinerja NPL/NPF antara kedua bank, dan NPL/NPF pada bank konvensional lebih unggul ketimbang bank syariah. 3) Tidak adanya dismilaritas kinerja ROA antara kedua bank, dan ROA pada bank konvensional lebih unggul ketimbang bank syariah. 4) Tidak adanya dismilaritas kinerja BOPO antara kedua bank, dan BOPO pada bank konvensional lebih unggul ketimbang bank syariah. 5) Tidak adanya dismilaritas kinerja LDR/FDR antara kedua bank, dan LDR/FDR pada bank syariah lebih unggul ketimbang bank konvensional.
\end{abstract}

Kata Kunci: Bank Konvensional, Bank Syariah, Kinerja Keuangan, Rasio Keuangan 


\section{Pendahuluan}

Uang merupakan hal yang oleh seluruh penduduk dirasa penting dan harus mereka miliki. Karena, seumpama ingin membeli sesuatu harus memanfaatkan uang, jadi uang diperlukan untuk memuaskan kebutuhan hidupnya. Untuk menyimpan hartanya penduduk mengamanahkan kepada suatu lembaga perbankan. Karena, selain dianggap merasa aman penduduk pun dapat menuai keuntungan dari program kerja lembaga perbankan tersebut. Beralaskan pada Undang-Undang RI Nomor 10 tahun 1998 Tentang Perbankan, bank merupakan badan usaha yang menghimpun dana dari masyarakat dalam bentuk simpanan dan menyalurkannya kepada masyarakat dalam bentuk kredit dan atau bentuk-bentuk lainnya dalam rangka meningkatkan taraf hidup rakyat banyak. Beralaskan pada taktik penetapan harga lembaga keuangan perbankan dibagi menjadi 2 (dua) sektor, yakni bank yang beralaskan pada dasar konvensional dan bank yang beralaskan pada dasar syariah.

Bank konvensional yakni bank yang berproses menurut dasar konvensional dan dalam menuai labanya dengan menjalankan sistem bunga. Sementara itu bank syariah yakni bank yang berproses menurut dasar syariah Islam dan dalam menuai labanya dengan menjalankan sistem bagi hasil.

Kendatipun di Indonesia memiliki 2 (dua) bank dengan sistem yang berlainan, akan tetapi secara garis besar bahwa umumnya bank di Indonesia mengikuti sistem bank konvensional. Ditinjau dari salah satu aspek yakni aspek sejarah, telah diketahui bahwa bank konvensional ialah bank pertama yang berpraktik. Bank konvensional perdana yakni Bank Negara Indonesia dibentuk pada 5 Juli 1994. Dan waktu perdana bank syariah masuk tahun 1991 dengan berdirinya Bank Muamalat Indonesia tanggal 1 November. Untuk lebih jelasnya mengenai berapa keseluruhan bank di Indonesia, bisa kita perhatikan pada tabel 1. Beralaskan tabel 1 pada tahun 2019 total bank di Indonesia yang tercatat sejumlah 110 bank, lebih sedikit ketimbang pada tahun 2018 yang tercatat sejumlah 115 bank.
Tabel 1 Daftar Bank Umum Indonesia

\begin{tabular}{ccc}
\hline BANK & JENIS BANK & TOTAL \\
UMUM & & BANK \\
\hline Bank & Bank Persero & 4 \\
Konvensional & Bank Pembangunan Daerah & 24 \\
& Bank Swasta Nasional & 60 \\
& Kantor Cabang Bank Asing & 8 \\
\hline \multicolumn{2}{l}{ Total bank Konvensional } & 96 \\
\hline \multicolumn{2}{c}{ Bank } & Bank Pembangunan Daerah \\
Syariah & Bank Swasta Nasional & 2 \\
\hline \multicolumn{2}{l}{ Total Bank Syariah } & 12 \\
\hline \multicolumn{2}{l}{ Total Bank Umum Di Indonesia } & 110 \\
\hline \multicolumn{2}{l}{ Sumber: ww.ojk.go.id, Dikerjakan peneliti, 2020 }
\end{tabular}

Dan dapat ditinjau bahwa rata-rata bank umum di Indonesia mengikuti sistem konvensional yaitu sejumlah 96 bank, sementara itu bank syariah hanya ada 14 bank saja.

Ditinjau dari kejadian saat ini, bahwa kendatipun mayoritas penduduk Indonesia beragama Islam, akan tetapi sebagian besar penduduk lebih mempercayakan hartanya pada bank konvensional. Dan juga minimnya pemasyarakatan pengenalan mengenai produk-produk bank syariah yang menimbulkan masyakat lebih memilih bank konvensional karena dirasa pada bank syariah mereka tidak akan menuai keuntungan ketimbang pada bank konvensional. Akan tetapi selama 5 tahun terakhir minat masyarakat kepada bank syariah mulai meningkat, pada tahun 2015 market share bank syariah mendekati $4 \%$ naik dari tahun sebelumnya. Sampai pada tahun 2019 market share bank syariah terus naik, terlihat seperti pada grafik market share di gambar 1.

Market share atau pangsa pasar yakni sebuah grafik yang mengilustrasikan tingkat persentase perolehan oleh suatu lembaga agar kita dapat mendapati lembaga mana yang lebih unggul dipasaran. Beralaskan gambar 1.1 grafik market share per Oktober 2019, bank konvensional menuai persentase $93,99 \%$ dan bank syariah menuai persentase $6,01 \%$. Hal ini diartikan bahwa pangsa pasar perbankan dikuasai oleh bank 
konvensional dikarenakan banyaknya penduduk yang lebih memilih bank konvensional. Kendatipun begitu bagi bank syariah $6,01 \%$ merupakan angka yang sangat bagus dikarenakan setelah 28 tahun akhirnya persentase market share bank syariah menyentuh angka $6 \%$.

\section{Gambar 1. Market Share Lembaga Perbankan Periode Oktober 2019}

\section{MARKET SHARE}

घank Konvensional $\quad$ Bank Syariah

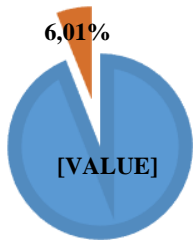

Sumber: www.ojk.go.id, Dikerjakan peneliti, 2020

Ada 1 (satu) kesamaan yang kentara Bank konvensional dan bank syariah yaitu dari sudut sasaran dikeluarkannya laporan keuangan. Seperti yang telah diketahui bahwa laporan keuangan bermaksud untuk menginformasikan keuangan suatu lembaga perbankan kepada khalayak luas. Kemudian perbedaan yang paling kentara dari bank konvensional dan bank syariah yakni dari sudut sistem untuk menuai keuntungannya. Bank konvensional menyematkan dasar bunga sementara itu bank syariah menyematkan dasar bagi hasil. Dasar bunga pada bank syariah ini sangat tidak ditoleransi untuk dipakai, karena dalam Islam bunga dianggap riba dan riba hukumnya haram. Akan tetapi, sangat disayangkan bahwa masih lumayan banyak penduduk Indonesia yang beranggapan negatif yakni berpikir bahwa sistem bagi hasil sama saja dengan bunga. Oleh karena itu, perlunya pemasyarakatan atas informasi mengenai produk-produk bank syariah sehingga masyarakat diluar sana dapat mengetahui mengenai bank syariah.

Beralaskan kejadian diatas, yaitu bahwa minimnya minat penduduk Indonesia untuk memanfaatkan jasa bank syariah dalam mengelola keuangannya.
Mayoritas penduduk lebih memilih bank konvensional dibandingkan bank syariah. Karena dirasa pada bank syariah mereka tidak akan menuai keuntungan ketimbang pada bank konvensional. Maka cara untuk mengenal lebih dalam apakah kualitas kinerja keuangan dikedua sistem perbankan ini memiliki perbedaan yang cukup signifikan atau tidak. Cara untuk mengetahuinya yaitu dengan cara membandingkannya yang akan dibanding-kan adalah rasio-rasio kinerja keuangan lembaga perbankan tersebut. Rasio yang akan dibandingkan adalah rasio permodalan akan diwakili oleh rasio Capital Adequacy Ratio (CAR), rasio kualitas aset akan diwakili oleh rasio Non Performing Loan (NPL) atau Non Performing Finance (NPF), rasio rentabilitas akan diwakili oleh rasio Return On Asset (ROA), rasio efisiensi akan diwakili oleh rasio Beban Operasional dibagi Pendapatan Operasional (BOPO), dan rasio likuiditas akan diwakili oleh rasio Loan to Deposit Ratio (LDR) atau Finance to Deposit Ratio (FDR).

Adapun tujuan yang ingin dicapai yakni ingin mendapati ada tidaknya dismilaritas bank konvensional dan bank syariah dalam kinerja keuangannya. Dan demi mendapati lembaga perbankan mana yang lebih unggul beralaskan pada rasio permodalan, rasio kualitas aset, rasio rentabilitas, rasio efisiensi, dan rasio likuiditas.

\section{Pengembangan Hipotesis Capital Adequacy Ratio (CAR)}

CAR ialah perwakilan dari rasio permodalan yang bermaksud demi menaksir tingkat keseluruhan modal lembaga perbankan. Menurut Irham Fahmi (2015:153) definisi CAR yaitu CAR ialah pengukuran kecukupan modal yang bank punya yang dipakai untuk mengatasi aktiva yang menimbulkan risiko.

Rasio CAR yang baik yakni tingkat rasio yang diatas $8 \%$. Untuk menaksir nilai rasio CAR boleh memakai rumus ini:

$$
\mathrm{CAR}=\frac{\text { Modal Bank }}{\text { ATMR }} \times 100 \%
$$


Beralaskan penelitian terdahulu menurut Silviana (2016) mengatakan bahwa rasio CAR lebih unggul kinerjanya pada bank konvensional ketimbang bank syariah. Sementara itu menurut Murni \& Joubert.B. Maramis (2017), Solikah et al., (2017), dan Hardianti \& Saifi (2018) mengatakan bahwa rasio CAR lebih unggul kinerjanya pada bank syariah ketimbang bank konvensional.

Ditinjau dari adanya dismilaritas hasil dari berbagai sumber penelitian terdahulu, maka pada kesempatan ini peneliti akan mengembangkan hipotesis penelitian berikut:

$\mathrm{H}_{\mathrm{a} 1}$ : Adanya dismilaritas kinerja CAR antara kedua bank.

\section{Non Performing Loan (NPL) atau Non Performing Finance (NPF)}

NPL/NPF ialah perwakilan dari rasio kualitas aset. NPL yakni rasio yang dipakai oleh bank konvensional, sementara itu NPF yakni rasio yang dipakai oleh bank syariah. Menurut Kasmir (2013:155) definisi NPL/NPF yaitu:

"NPL/NPF adalah kredit/pembiayaan bermasalah yang disebabkan pihak nasabah yang dengan sengaja atau tidak sengaja tidak dapat mengembalikan dana sesuai perjanjian."

Kendatipun istilah yang dipakai berlainan tetapi tetap memiliki tujuan yang sama yaitu untuk menaksir tingkat kredit atau pembiayaan yang bermasalah. Rasio NPL/NPF yang baik yaitu tingkat rasio yang kurang dari 5\%. Untuk menaksir tingkat rasio NPL/NPF boleh memakai rumus ini:

$$
\begin{gathered}
\text { NPL }=\frac{\text { Kredit Bermasalah }}{\text { Total Kredit }} \times 100 \% \\
\text { Atau } \\
\text { NPF }=\frac{\text { Pembiayaan Bermasalah }}{\text { Total Kredit }} \times 100 \%
\end{gathered}
$$

Beralaskan penelitian terdahulu menurut Murni \& Joubert.B.Maramis (2017), Solikah et al., (2017) dan Hardianti \& Saifi (2018) mengatakan bahwa rasio NPL/NPF lebih unggul kinerjanya pada bank konvensional ketimbang bank syariah. Sementara itu menurut Silviana (2016) mengatakan bahwa rasio NPL/NPF lebih unggul kinerjanya pada bank syariah ketimbang bank konvensional.

Ditinjau dari adanya dismilaritas hasil dari berbagai sumber penelitian terdahulu, maka pada kesempatan ini peneliti akan mengembangkan hipotesis penelitian berikut:

$\mathrm{H}_{\mathrm{a} 2}$ : Adanya dismilaritas kinerja NPL/NPF antara kedua bank.

\section{Return On Asset (ROA)}

ROA ialah perwakilan dari rasio rentabilitas bermaksud menaksir kualitas laba yang diperoleh lembaga perbankan. Menurut Kasmir (2014:201) ROA ialah rasio yang menggambarkan tingkat pendapatan bank.

Semakin tinggi tingkat ROA yang didapat maka dapat dikatakan keuntungan yang didapat juga tinggi, begitupun sebaliknya seumpama tingkat ROA yang didapat semakin kecil maka dapat dikatakan keuntungan yang didapat sedikit dan dapat diidentifikasikan bahwa adanya suatu masalah. Dalam mencari hasil rasio ROA boleh memakai rumus seperti di bawah ini:

$$
\text { ROA }=\frac{\text { Laba bersih setelah Pajak }}{\text { total aset }} \times 100 \%
$$

Beralaskan penelitian terdahulu menurut Murni \& Joubert.B.Maramis (2017), dan Solikah et al., (2017), mengatakan bahwa rasio ROA lebih unggul kinerjanya pada bank konvensional ketimbang bank syariah. Sementara itu menurut Silviana (2016) mengatakan bahwa rasio ROA lebih unggul kinerjanya pada bank syariah ketimbang bank konvensional.

Ditinjau dari adanya dismilaritas hasil dari berbagai sumber penelitian terdahulu, maka pada kesempatan ini peneliti akan mengembangkan hipotesis penelitian berikut:

$\mathrm{H}_{\mathrm{a} 3}$ : Adanya dismilaritas kinerja ROA antara kedua bank.

\section{Beban Operasional dibagi Pendapatan Operasional (BOPO)}

BOPO merupakan perwakilan rasio efisiensi bermaksud menaksir keterampilan manajemen mengelola suatu sumber daya. 
BOPO ialah rasio efisiensi bank dalam mengendalikan biaya operasional terhadap pendapatan operasional".

Rasio BOPO dapat dikatakan efisien yaitu tingkat rasio BOPO semakin rendah. Dalam mencari hasil rasio BOPO boleh memakai rumus seperti di bawah ini:

$$
\text { BOPO }=\frac{\text { Biaya Operasional }}{\text { Pendapatan Operasional }} \times 100 \%
$$

Beralaskan penelitian terdahulu menurut Hardianti \& Saifi (2018) mengatakan bahwa rasio BOPO lebih unggul kinerjanya pada bank konvensional ketimbang bank syariah. Sementara itu menurut Silviana (2016) dan Solikah et al., (2017), mengatakan bahwa rasio BOPO lebih unggul kinerjanya pada bank syariah ketimbang bank konvensional.

Ditinjau dari adanya dismilaritas hasil dari berbagai sumber penelitian terdahulu, maka pada kesempatan ini peneliti akan mengembangkan hipotesis penelitian berikut:

$\mathrm{H}_{\mathrm{a} 4}$ : Adanya dismilaritas kinerja BOPO antara kedua bank.

\section{Loan to Deposit Ratio (LDR) atau Finance to Deposit Ratio (FDR)}

LDR/FDR merupakan perwakilan dari rasio likuiditas. LDR yakni rasio yang dipakai bank konvensional, sementara itu FDR yakni rasio yang dipakai oleh bank syariah. Menurut Kasmir (2014:225) definisi LDR yaitu LDR/FDR ialah rasio pengukuran total kredit/pembiayaan bermasalah dengan total dana yang dimiliki oleh bank tersebut.

Kendatipun istilah yang digunakan berlainan tetapi memiliki tujuan yang sama yaitu untuk menaksir tingkat perbandingan total kredit/pembiayaan dengan besaran dana penduduk yang dimiliki. Seumpama tingkat rasio LDR/FDR tinggi maka dapat dikatakan bahwa semakin rendah tingkat likuiditasnya. Dalam mencari hasil rasio LDR/FDR boleh memakai rumus seperti di bawah ini:

$$
\begin{gathered}
\text { LDR }=\frac{\text { Total Kredit }}{\text { Dana Pihak Ketiga }} \times 100 \% \\
\text { Atau } \\
\text { FDR }=\frac{\text { Total Pembiayaan }}{\text { Dana Pihak Ketiga }} \times 100 \%
\end{gathered}
$$

Beralaskan penelitian terdahulu menurut Hardianti \& Saifi (2018) mengatakan bahwa rasio LDR/FDR lebih unggul kinerjanya pada bank konvensional ketimbang bank syariah. Sementara itu menurut Murni \& Joubert.B.Maramis (2017), Solikah et al., (2017) dan Silviana (2016) mengatakan bahwa rasio LDR/FDR lebih unggul kinerjanya pada bank syariah ketimbang bank konvensional.

Ditinjau dari adanya dismilaritas hasil dari berbagai sumber penelitian terdahulu, maka pada kesempatan ini peneliti akan mengembangkan hipotesis penelitian berikut:

$\mathrm{H}_{\mathrm{a} 5}$ : Adanya dismilaritas kinerja LDR/FDR antara kedua bank.

\section{Metode Penelitian}

Pada penelitian ini, peneliti memakai metode deskriptif komparatif melalui pendekatan kuantitatif. Metode deskriptif dipakai untuk mengilustrasikan rasio-rasio keuangan yaitu CAR, NPL/NPF, ROA, BOPO, dan LDR/FDR. Kemudian metode komparatif dipakai demi mengetahui perbandingan kedua bank tersebut. Dan pendekatan kuantitatif dipakai untuk mendapati apakah ada dismilaritas kinerja keuangan beralaskan pada rasio-rasio keuangannya.

Untuk data yang dipakai yakni data yang berpangkal dari data sekunder dan merupakan model data time series, karena pada penelitian ini meneliti data dari tahun 2015-2019. Data yang dipakai yaitu CAR, NPL/NPF, ROA, BOPO, dan LDR/FDR. Basis pengumpulan data berasal dari annual report pada masing-masing bank yang didapat pada situs resmi bank tersebut.

Teknik pengumpulan datanya memakai teknik studi pustaka dan studi dokumenter. Teknik studi pustaka yakni 
teknik penghimpunan data yang berpangkal pada jurnal, artikel, buku, dan media lainnya. Studi dokumenter yakni teknik penghimpunan data yang berpangkal pada annual report lembaga perbankan.

Berikut subjek pada penelitian ini:

1) Populasi

Populasi ialah induk yang berisi kumpulan sampel. Populasi yang dipakai yakni 96 Bank Umum Konvensional dan 14 Bank Umum Syariah.

2) Sampel

Sampel ialah anak dari populasi atau salah satu bagian dari populasi. Teknik pengambilan sampel yang dipakai yakni teknik simple random sampling dengan pengambilan sampel acak sistematis. Total sampel yang akan dipakai sebanyak 6 bank konvensional dan 7 bank syariah. Untuk pengambilan sampel bank konvensional menggunakan pola 1-15-30-45-60. Dan untuk pengambilan sampel bank syariah menggunakan pola 3-5-7-9-11.

Maka berdasarkan pola yang telah dibuat, sampel penelitian yang didapatkan yaitu:

Tabel 2 Data Sampel

\begin{tabular}{|l|l|}
\hline \multicolumn{1}{|c|}{$\begin{array}{c}\text { Bank } \\
\text { Konvensional }\end{array}$} & \multicolumn{1}{c|}{ Bank Syariah } \\
\hline $\begin{array}{l}\text { PT. Bank Rakyat } \\
\text { Indonesia (persero) } \\
\text { tbk }\end{array}$ & $\begin{array}{l}\text { PT. Bank Muamalat } \\
\text { Indonesia }\end{array}$ \\
\hline $\begin{array}{l}\text { PT. Bank HSBC } \\
\text { Indonesia }\end{array}$ & $\begin{array}{l}\text { PT. Bank BRI } \\
\text { Syariah }\end{array}$ \\
\hline $\begin{array}{l}\text { PT. Bank MNC } \\
\text { Internasional tbk }\end{array}$ & $\begin{array}{l}\text { PT. Bank BNI } \\
\text { Syariah }\end{array}$ \\
\hline $\begin{array}{l}\text { PT. Bank } \\
\text { Commonwealth }\end{array}$ & $\begin{array}{l}\text { PT. Bank Mega } \\
\text { Syariah }\end{array}$ \\
\hline $\begin{array}{l}\text { PT. Bank Fama } \\
\text { Internasional }\end{array}$ & $\begin{array}{l}\text { PT. Bank Syariah } \\
\text { Bukopin }\end{array}$ \\
\hline
\end{tabular}

Sumber: www.ojk.go.id, Dikerjakan peneliti, 2020

Untuk lebih menyederhanakan penelitian ini, maka dibuat sebuah kerangka pikiran yaitu dapat dicermati pada gambar berikut:
Gambar 2 Kerangka Pikiran

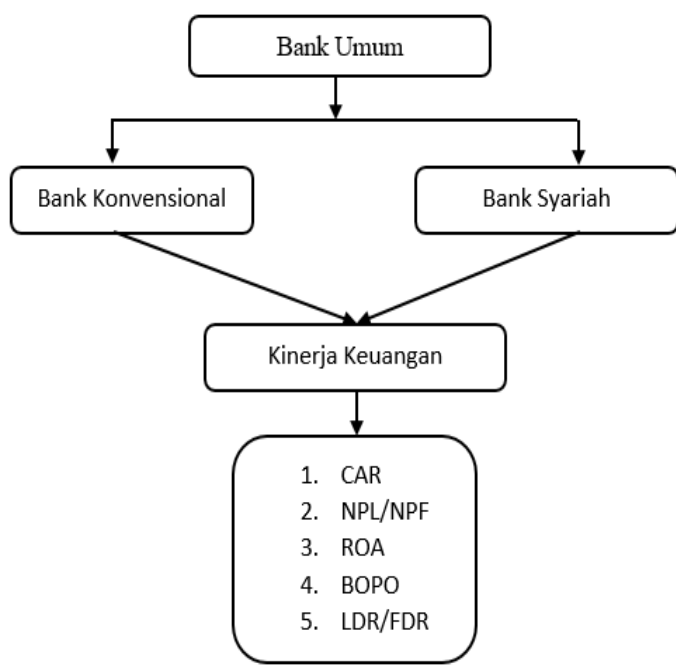

Sumber: Dikerjakan peneliti, 2020

\section{Teknik Analisis Data}

1) Uji Statistik Deskriptif

Uji statistik deskriptif yakni uji yang menyediakan gambaran untuk mendapati lembaga perbankan mana yang lebih unggul dari segi nilai mean.

2) Uji Hipotesis Dua Rata-Rata (Independent Sample t-Test)

Uji hipotesis dua rata-rata (Independent Sample t-Test) yakni uji yang menyediakan gambaran berupa apakah dari kedua lembaga perbankan ini terdapat perbedaan atau tidak beralaskan pada kinerja keuangannya.

\section{Hasil Dan Pembahasan Uji Statistik Deskriptif}

Tabel 3 Hasil Uji Statistik Deskriptif Bank Konvensional

\begin{tabular}{|l|r|r|r|r|r|}
\multicolumn{7}{c|}{ Descriptive Statistics } \\
& N & Min & Max & \multicolumn{1}{c|}{ Mean } & $\begin{array}{c}\text { Std. } \\
\text { Deviation }\end{array}$ \\
\hline CAR & 25 & 12.58 & 29.38 & 22.3760 & 4.01650 \\
NPL & 25 & .88 & 4.42 & 2.4000 & 1.06920 \\
ROA & 25 & -7.47 & 3.84 & 1.0124 & 2.35351 \\
BOPO & 25 & 68.40 & 180.62 & 93.0976 & 22.39297 \\
LDR & 25 & 70.01 & 101.39 & 87.5980 & 6.15150 \\
Valid N & 25 & & & & \\
(listwise) & & & & & \\
\hline
\end{tabular}

Sumber: Dikerjakan peneliti, 2020 
Tabel 4 Hasil Uji Statistik Deskriptif Bank Syariah

\begin{tabular}{|l|r|r|r|r|r|}
\hline & Descriptive Statistics \\
\hline CAR & 25 & 12.00 & 29.72 & 18.0748 & 4.41671 \\
NPF & 25 & 1.40 & 4.97 & 2.8976 & 1.13915 \\
ROA & 25 & .02 & 2.63 & .7592 & .68270 \\
BOPO & 25 & 81.26 & 99.60 & 93.6380 & 5.09914 \\
FDR & 25 & 71.87 & 98.49 & 85.5396 & 8.03399 \\
Valid N & 25 & & & & \\
(listwise) & & & & \\
\hline
\end{tabular}

Sumber: Dikerjakan peneliti, 2020

Beralaskan pada hasil kedua tabel di atas, maka hasil yang didapat dari uji statistik deskriptif seperti berikut:

1. Pada rasio CAR diperoleh nilai minimum bank konvensional sejumlah $12,58 \%$ dan bank syariah sejumlah $12,00 \%$. Nilai maksimum pada bank konvensional sejumlah $29.38 \%$ dan bank syariah sejumlah $29,72 \%$. Ratarata CAR bank konvensional sejumlah $22,3760 \%$ dan bank syariah sejumlah $18,0748 \%$. Standar deviasi pada bank konvensional sejumlah $4,01650 \%$ dan bank syariah sejumlah $4,41671 \%$. Diketahui bahwa pada bank konvensional nilai standar deviasi $4,01650 \%$ < mean 22,3760\%, artinya tidak terdapat kesenjangan yang relatif besar antara nilai minimum dan maksimum. Dan pada bank syariah nilai standar deviasi $4,41671 \%$ < mean $18,0748 \%$, artinya tidak terdapat kesenjangan yang relatif besar antara nilai minimum dan maksimum.

Kemudian ditinjau dari sudut mean hasil perbandingan CAR bank konvensional 22,3760\% lebih besar dari bank syariah 18,0748\%. Maka dari itu, dapat dikatakan bahwa pada rasio permodalan yang wakili rasio CAR pada bank konvensional lebih unggul ketimbang bank syariah. Hal itu disebabkan karena jumlah modal pada bank konvensional lebih banyak dibanding bank syariah. Karena CAR yang baik ialah yang nilainya semakin tinggi. Hal itu sesuai dengan penelitian
Silviana (2016), yang mengatakan CAR bank konvensional lebih unggul ketimbang bank syariah.

2. Pada rasio NPL/NPF diperoleh nilai minimum pada bank konvensional sejumlah $0,88 \%$ dan bank syariah sejumlah $1,40 \%$. Nilai maksimum pada bank konvensional sejumlah $4,42 \%$ dan bank syariah sejumlah $4,97 \%$. Rata-rata NPL/NPF pada bank konvensional sejumlah $2,4000 \%$ dan bank syariah sejumlah 2,8976\%. Standar deviasi pada bank konvensional sejumlah $1,06920 \%$ dan bank syariah sejumlah $1,13915 \%$. Diketahui bahwa pada bank konvensional nilai standar deviasi $1,06920 \%<$ mean 2,4000\%, artinya tidak terdapat kesenjangan yang relatif besar antara nilai minimum dan maksimum. Dan pada bank syariah nilai standar deviasi $1,13915 \%$ < mean $2,8976 \%$, artinya tidak terdapat kesenjangan yang relatif besar antara nilai minimum dan maksimum.

Kemudian ditinjau dari sudut mean NPL/NPF perbandingan bank konvensional dan bank syariah didapat hasil 2,4000\% < 2,8976\%. Maka dari itu, dapat dikatakan bahwa pada rasio kualitas aset yang diwakili rasio NPL/NPF pada bank konvensional lebih unggul ketimbang bank syariah. Hal itu disebabkan karena tingkat kredit macet yang terjadi di bank konvensional lebih sedikit dibanding pembiayaan macet pada bank syariah. Karena NPL/NPF yang baik ialah yang nilainya semakin rendah. Hal itu sesuai dengan penelitian Solikah et al., (2017) dan Hardianti \& Saifi (2018) yang menyatakan NPL?NPF bank konvensional lebih unggul ketimbang bank syariah.

3. Pada rasio ROA diperoleh nilai minimum pada bank konvensional sejumlah $-7,47 \%$ dan bank syariah sejumlah $0,02 \%$. Nilai maksimum pada bank konvensional sejumlah 3,84\% dan bank syariah sejumlah 2,63\%. Rata-rata bank konvensional sejumlah 1,0124\% dan bank syariah sejumlah $0,7592 \%$. Dan standar deviasi bank konvensional sejumlah $2,35351 \%$ dan bank syariah 
sejumlah 0,68270\%. Diketahui bahwa pada bank konvensional nilai standar deviasi 2,35351\% > mean 1,0124\%, artinya terdapat kesenjangan yang relatif besar antara nilai minimum dan maksimum. Dan pada bank syariah nilai standar deviasi $0,68270 \%<$ mean $0,7592 \%$, artinya tidak terdapat kesenjangan yang relatif besar antara nilai minimum dan maksimum.

Kemudian ditinjau dari sudut mean ROA perbandingan bank konvensional dan bank syariah didapat hasil 1,0124\% $>0,7592 \%$. Maka dari itu, dapat dikatakan bahwa pada rasio rentabilitas yang diwakili oleh rasio ROA pada bank konvensional lebih unggul ketimbang bank syariah. Hal itu dapat disebabkan karena banyaknya nasabah yang memilih menggunakan jasa bank konvensional, sehingga makin banyaknya transaksi yang dapat meningkatkan rasio ROA. Karena ROA yang baik ialah yang nilainya semakin tinggi. Hal itu sesuai dengan penelitian Solikah et al., (2017), yang menyatakan ROA bank konvensional lebih unggul ketimbang bank syariah.

4. Pada rasio BOPO diperoleh nilai minimum pada bank konvensional sejumlah $68,40 \%$ dan bank syariah sejumlah $81,26 \%$. Nilai maksimum pada bank konvensional sejumlah $180,62 \%$ dan bank syariah sejumlah $99,60 \%$. Rata-rata BOPO pada bank konvensional sejumlah 93,0976\% dan bank syariah sejumlah 93,6380\%. Standar deviasi bank konvensional sejumlah 22,39297\% dan bank syariah sejumlah 5,09914\%. Diketahui bahwa pada bank konvensional nilai standar deviasi 22,39297\% < mean 93,0976\%, artinya tidak terdapat kesenjangan yang relatif besar antara nilai minimum dan maksimum. Dan pada bank syariah nilai standar deviasi $5,09914 \%$ < mean $93,6380 \%$, artinya tidak terdapat kesenjangan yang relatif besar antara nilai minimum dan maksimum.

Kemudian ditinjau dari sudut mean BOPO perbandingan bank konvensional dan bank syariah didapat hasil $93,0976 \%<93,6380 \%$. Maka dari itu, dapat dikatakan bahwa pada rasio efisiensi yang diwakili oleh rasio BOPO pada bank konvensional lebih unggul ketimbang bank syariah. Hal itu disebabkan karena bank konvensional lebih baik dalam menghasilkan laba dengan meningkatkan pendapatan operasional dan menekan biaya-biaya operasional. Karena BOPO yang baik ialah yang nilainya semakin rendah. Hal itu sesuai dengan penelitian Hardianti \& Saifi (2018) yang menyatakan BOPO bank konvensional lebih unggul ketimbang bank syariah.

5. Pada rasio LDR/FDR diperoleh nilai minimum pada bank konvensional sejumlah $70,01 \%$ dan bank syariah sejumlah $71,87 \%$. Nilai maksimum pada bank konvensional sejumlah $101,39 \%$ dan bank syariah sejumlah $98,49 \%$. Rata-rata LDR/FDR pada bank konvensional sejumlah $87,5980 \%$ dan bank syariah sejumlah $85,5396 \%$. Standar deviasi pada bank konvensional sejumlah $6,15150 \%$ dan bank syariah sejumlah 8,03399\%. Diketahui bahwa pada bank konvensional nilai standar deviasi $6,15150 \%$ < mean 87,5980\%, artinya tidak terdapat kesenjangan yang relatif besar antara nilai minimum dan maksimum. Dan pada bank syariah nilai standar deviasi $8,03399 \%$ < mean $85,5396 \%$, artinya tidak terdapat kesenjangan yang relatif besar antara nilai minimum dan maksimum.

Kemudian ditinjau dari sudut mean LDR/FDR perbandingan bank konvensional dan bank syariah didapat hasil 87,5980\% > 85,5396\%. Maka dari itu, dapat dikatakan bahwa pada rasio likuiditas yang diwakili oleh rasio LDR/FDR bank syariah lebih unggul ketimbang bank konvensional. Meskipun sebenarnya keduanya sudah sesuai dengan ketentuan BI. Hal itu disebabkan karena pada bank syariah telah melaksanakan fungsi intermediasinya dengan baik yaitu tidak terlalu tinggi mauapun rendah dalam penyaluran pembiayaan. LDR/FDR yang baik ialah yang tidak kurang atau tidak melebihi dari standar BI. Hal itu sesuai dengan penelitian Murni \& 
Joubert.B.Maramis (2017), yang menyakan LDR/FDR bank syariah lebih unggul ketimbang bank konvensional.

\section{Uji Hipotesis Dua Rata-Rata (Independent Sample t-Test)}

Tabel 5 Uji Hipotesis Dua Rata-Rata (Independent Sample t-Test)

\begin{tabular}{|c|c|c|c|c|c|c|}
\hline \multicolumn{7}{|c|}{ Independent Samples Test } \\
\hline & & \multicolumn{2}{|c|}{$\begin{array}{c}\text { Levene's Test } \\
\text { for Equality } \\
\text { of Variances }\end{array}$} & \multicolumn{3}{|c|}{$\begin{array}{l}\text { t-test for Equality of } \\
\text { Means }\end{array}$} \\
\hline & & $\mathrm{F}$ & Sig. & $\mathrm{t}$ & df & $\begin{array}{l}\text { Sig. (2- } \\
\text { tailed) }\end{array}$ \\
\hline \multirow[t]{2}{*}{ CAR } & Equal variances assumed & .663 & .420 & 3.602 & 48 & .001 \\
\hline & $\begin{array}{l}\text { Equal variances not } \\
\text { assumed }\end{array}$ & & & 3.602 & 47.573 & .001 \\
\hline \multirow{2}{*}{$\begin{array}{l}\text { NPL/ } \\
\text { NPF }\end{array}$} & Equal variances assumed & .138 & .712 & -1.592 & 48 & .118 \\
\hline & $\begin{array}{l}\text { Equal variances not } \\
\text { assumed }\end{array}$ & & & -1.592 & 47.809 & .118 \\
\hline \multirow[t]{2}{*}{ ROA } & Equal variances assumed & 8.808 & .005 & .517 & 48 & .608 \\
\hline & $\begin{array}{l}\text { Equal variances not } \\
\text { assumed }\end{array}$ & & & .517 & 28.011 & .609 \\
\hline \multirow[t]{2}{*}{ BOPO } & Equal variances assumed & 6.686 & .013 & -.118 & 48 & .907 \\
\hline & $\begin{array}{l}\text { Equal variances not } \\
\text { assumed }\end{array}$ & & & -.118 & 26.482 & .907 \\
\hline \multirow{2}{*}{$\begin{array}{l}\text { LDR/ } \\
\text { FDR }\end{array}$} & Equal variances assumed & 5.989 & .018 & 1.017 & 48 & .314 \\
\hline & $\begin{array}{l}\text { Equal variances not } \\
\text { assumed }\end{array}$ & & & 1.017 & 44.943 & .315 \\
\hline
\end{tabular}

Sumber: Dikerjakan peneliti, 2020

Beralaskan pada tabel di atas hasil yang didapat yakni seperti berikut:

1. Pada rasio CAR nilai $F$ hitung sejumlah 0,663 dengan nilai sig. 0,420 . Beralaskan pada kriteria nilai $0,420>$ 0,05 , maka untuk uji t kita akan melihat pada baris Equal variances assumed. Sehingga diperoleh nilai $t$ hitung sejumlah 3,602 dengan nilai sig. 0,001. Beralaskan pada kriteria nilai $0,001<$ 0,05 . Jadi, dapat kita ambil hasilnya yakni $\mathrm{H}_{\mathrm{a} 1}$ diterima artinya ada dismilaritas kinerja CAR antara bank konvensional dan bank syariah. Perbedaan kinerja ini karena pada bank konvensional lebih unggul dalam menunjukkan kemampuannya dalam menyediakan dana yang digunakan untuk mengatasi kemungkinan risiko kerugian. Bank syariah pun sudah baik dalam menjalankan kinerja CAR ini, akan tetapi bank konvensional masih tetap unggul.

2. Pada rasio NPL/NPF nilai $F$ hitung sejumlah 0,138 dengan nilai sig. 0,712. Beralaskan pada kriteria nilai $0,712>$ 0,05 , maka untuk uji t kita akan melihat pada baris Equal variances assumed. Sehingga diperoleh nilai $\mathrm{t}$ hitung sejumlah -1,592 dengan nilai sig. 0,001. Beralaskan pada kriteria nilai $0,001<$ 0,05 . Jadi, dapat kita ambil hasilnya yakni $\mathrm{H}_{\mathrm{a} 2}$ diterima artinya ada dismilaritas kinerja NPL/NPF antara bank konvensional dan bank syariah. Perbedaan kinerja ini tentu saja disebabkan karna kemampuan bank tersebut dalam mencegah kredit/pembiayaan macet. Bank konvensional lebih mampu menekan angka kredit macet ketimbangan bank syariah.

3. Pada rasio ROA nilai $\mathrm{F}$ hitung sejumlah 8,808 dengan nilai sig. 0,005 . Beralaskan pada kriteria nilai $0,005<$ 0,05, maka untuk uji t kita akan melihat pada baris Equal variances not assumed. Sehingga diperoleh nilai $\mathrm{t}$ hitung sejumlah 0,517 dengan nilai sig. 0,609 . Beralaskan pada kriteria nilai $0,609>0,05$. Jadi, dapat kita ambil hasilnya yakni $\mathrm{H}_{\mathrm{a} 3}$ ditolak artinya tidak ada dismilaritas kinerja ROA antara bank konvensional dan bank syariah. Dapat dikatakan bahwa kemampuan bank konvensional dan bank syariah dalam memperoleh pendapatan samasama unggul. Bank konvensional dan bank syariah mampu memperoleh pendapatan yang tinggi dengan sistem dan produk-produk bank tersebut, untuk itu tidak ada perbedaan dalam kinerja rentabilitas ini. Rasio ROA yang tinggi akan menarik minat investor, maka dari itu baik bank konvensional maupun bank syariah harus memperhatikan rasio ROA agar selalu memperoleh hasil yang tinggi.

4. Pada rasio BOPO nilai $F$ hitung sejumlah 6,686 dengan nilai sig. 0,013. Beralaskan pada kriteria nilai $0,013<$ 0,05, maka untuk uji t kita akan melihat pada baris Equal variances not assumed. Sehingga diperoleh nilai $\mathrm{t}$ hitung sejumlah $-0,118$ dengan nilai sig. 0,907 . Beralaskan pada kriteria nilai $0,907>0,05$. Jadi, dapat kita ambil hasilnya yakni $\mathrm{H}_{\mathrm{a} 4}$ ditolak artinya tidak ada dismilaritas kinerja BOPO antara bank konvensional dan bank syariah. Dapat dikatakan bahwa baik bank konvesnional maupun bank syariah 
sama-sama sudah cukup baik dalam mengefisiensikan kegiatannya. Meskipun tidak ada perbedaaan dalam kinerja BOPO ini, akan tetapi bank konvensional lebih unggul ketimbang bank syariah.

5. Pada rasio $L D R / F D R$ nilai $F$ hitung sejumlah 5,989 dengan nilai sig. 0,018. Beralaskan pada kriteria nilai $0,018<$ 0,05 , maka untuk uji t kita akan melihat pada baris Equal variances not assumed. Sehingga diperoleh nilai $\mathrm{t}$ hitung sejumlah 1,017 dengan nilai sig. 0,314 . Beralaskan pada kriteria nilai $0,314>0,05$. Jadi, dapat kita ambil hasilnya yakni $\mathrm{H}_{\mathrm{a} 5}$ ditolak artinya tidak ada dismilaritas kinerja LDR/FDR antara bank konvensional dan bank syariah. Dapat dikatakan bahwa pada bank konvensional dan bank syariah tidak ada perbedaan dalam menjalankan fungsi intermediasi ini. Dalam menjalankan penyaluran kredit atau pembiayaan ini pun bank konvensional dan bank syariah telah sesuai dengan ketentuan BI. Maka dari itu, kinerja LDR/FDR pada kedua bank tidak ada perbedaan.

\section{Simpulan}

Berdasarkan hasil analisis dari penelitian yang telah dilakukan yaitu membandingkan kinerja keuangan Bank Konvensional dengan bank Syariah tahun 2015-2019, maka hasil yang diperoleh setelah menguji data penelitian dengan uji statistik deskriptif dan uji hipotesis dua rata-rata (Independent Sample t-Test), yaitu bahwasannya pada rasio permodal yang diproksikan dengan rasio CAR ternyata $\mathrm{H}_{\mathrm{a} 1}$ diterima artinya ada dismilaritas kinerja CAR antara bank konvensional dan bank syariah. Dan rasio permodalan pada bank konvensional lebih unggul ketimbang bank syariah. Pada rasio kualitas aset yang diproksikan dengan rasio NPL/NPF ternyata $\mathrm{H}_{\mathrm{a} 2}$ diterima artinya ada dismilaritas kinerja NPL/NPF antara bank konvensional dan bank syariah. Dan kualitas aset pada bank konvensional lebih unggul ketimbang bank syariah. Pada rasio rentabilitas yang diproksikan dengan rasio ROA ternyata $\mathrm{H}_{\mathrm{a} 3}$ ditolak artinya tidak ada dismilaritas kinerja ROA antara bank konvensional dan bank syariah. Dan rasio rentabilitas bank konvensional lebih unggul ketimbang bank syariah. Pada rasio efisiensi yang diproksikan dengan rasio BOPO ternyata $\mathrm{H}_{\mathrm{a} 4}$ ditolak artinya tidak ada dismilaritas kinerja BOPO antara bank konvensional dan bank syariah. Dan rasio efisiensi bank konvensional lebih unggul ketimbang bank syariah. Pada rasio likuiditas yang diproksikan dengan rasio LDR/FDR ternyata $\mathrm{H}_{\mathrm{a} 5}$ ditolak artinya tidak ada dismilaritas kinerja LDR/FDR antara bank konvensional dan bank syariah. Dan rasio likuiditas bank syariah lebih unggul ketimbang bank konvensional.

Dalam penelitian ini masih terdapat berbagai keterbatasan penelitian, yaitu pada sampel penelitian yang dipakai hanya sedikit yaitu 5 bank konvensional dan 5 bank syariah, variabel yang dipakai belum mencakup keseluruhan kinerja keuangan bank, dan tahun penelitian cukup terbatas yaitu hanya 5 tahun.

Adapun saran yang dapat peneliti berikan kepada peneliti selanjutnya, yaitu bagi peneliti selanjutnya diharapkan dapat menambahkan sampel penelitian sehingga tidak hanya 5 bank konvensional dan 5 bank syariah, diharapkan dapat menambahkan variabel penelitian yang belum peneliti teliti, serta diharapkan dapat memperpanjang waktu tahun penelitian sehingga dapat mendapatkan hasil yang lebih akurat.

Dan terdapat beberapa implikasi pada penelitian ini, yaitu implikasi manajerial bagi lembaga perbankan konvensional bahwasannya dari hasil penelitian diperoleh bahwa kinerja keuangan bank konvensional lebih unggul dari empat rasio keuangan yang diuji. Agar tetap mempertahankan keunggulan, bank konvensional bisa lebih meningkatkan kinerjanya agar dapat mendapatkan hasil yang lebih bagus lagi. Dan agar dapat menurunkan rasio LDR agar sesuai dengan standar dari BI, dengan cara tidak terlalu banyak mengalokasikan dana pada kredit.

Kemudian implikasi manajerial bagi lembaga perbankan syariah bahwasannya dari hasil penelitian diperoleh bahwa kinerja keuangan bank syariah tertinggal 
dibanding bank konvensional. dari kelima rasio keuangan yang diuji hanya satu rasio keuangan yang lebih unggul yaitu rasio FDR. Meskipun begitu kinerja keuangan bank syariah tidak berbeda secara signifikan dari kinerja keuangan bank konvensional. Agar bisa menandingi kinerja keuangan bank konvensional bank syariah perlu meningkatkan kinerja keuangannya, dengan cara pengelolaan aset yang benar, manajemen risiko yang baik, dan menjalankan fungsinya sebagai pihak intermediasi dengan baik.

\section{Daftar Pustaka}

Hardianti, D., \& Saifi, M. (2018). Analisis Perbandingan kinerja keuangan Bank Umum Konvensional dan Bank Umum Syariah Berdasaran Rasio Keuangan Bank (Studi pada Bank Umum Konvensional dan Bank Umum Syariah yang Terdaftar dan Diawasi oleh Otoritas Jasa Keuangan (OJK) Periode 2013 - 2016). Jurnal Administrasi Bisnis (JAB), 60(2), 1018.

Kasmir. (2017). Bank Dan Lembaga Keuangan Lainnya. Jakarta: PT. Raja Grafindo Persada.

Murni, B. T. S., \& Joubert.B.Maramis. (2017). Comparative Analysis of Financial Performance of Islamic and Conventional Banks. Jurnal EMBA, 5(2), 1759-1768.

Paramitha, D. A., \& Astuti, P. (2018). Analisis Perbandingan Kinerja Keuangan Pada Bank Syariah dan. Jurnal Akuntansi dan Ekonomi FE. UN PGRI Kediri, 38-50.

Rachman. (2019). Jurnal Akuntansi, Vol. 8, No. 2, November (2019) Analisis Perbandingan Kinerja Keuangan Bank Syariah Dengan Bank Konvensional. Kinerja, 8(2), 94-108.

Silviana, A. (2016). Analisis Perbandingan Kinerja Keuangan Bank Umum Konvensional dan Bank Umum Syariah di Indonesia (Studi Pada Perusahaan Perbankan Yang Terdaftar Di Bank Indonesia Tahun 2010 - 2014). Fakultas Ekonomi Dan
Bisnis Universitas Lampung, 1-62.

Solikah, H. M., Mardani, R. M., \& Wahono, B. (2017). Analisis Perbandingan Kinerja Keuangan Bank Umum Syariah Dengan Bank Umum Konvensional Di Indonesia (Studi Empiris Pada Perusahaan Perbankan di Bursa Efek Indonesia). Warta Ekonomi, 07(17), 64-77.

Sovia, S. E., Saifi, M., \& Husaini, A. (2019). ... Bank Konvensional Dan Bank Syariah Berdasarkan Rasio Keuangan Bank (Studi pada Bank Konvensional yang Terdaftar di BEI yang Memiliki Bank Syariah .... Jurnal Administrasi Bisnis (JAB), 73(2), $\quad$ 86-94. http://administrasibisnis.studentjourn al.ub.ac.id/index.php/jab/article/view $/ 1436$

Suhendro, D. (2018). Analisis Perbandingan Kinerja Keuangan Bank Umum Syariah VS Bank Umum Konvensional Di Indonesia Dengan Menggunakan Rasio Keuangan. Jurnal Masharif alSyariah: Jurnal Ekonomi dan Perbankan Syariah, 1-26.

Umardani, D., \& Muchlish, A. (2017). Analisis Perbandingan Kinerja Keuangan Bank Syariah Dan Bank Konvensional Di Indonesia. Jurnal Manajemen dan Pemasaran Jasa, 129-156.

Wahyuni, M., \& Efriza, R. E. (2017). Analisis Perbandingan Kinerja Keuangan Antara Bank Syariah dengan Bank Konvensional di Indonesia. Manajemen keuangan perbankan, 1-15.

Undang-Undang Republik Indonesia Nomor 10 tahun 1998 Tentang Perbankan

Undang-Undang Republik Indonesia Nomor 21 tahun 2008 Tentang Perbankan Syariah

www.bi.go.id diakses pada 05 Desember 2020 www.ojk.go.id diakses pada 05 Desember 2020 www.bri.co.id diakses pada 28 Juli 2021 
www.hsbc.co.id diakses pada 28 Juli 2021 www.mncbank.co.id diakses pada $28 \mathrm{Juli}$ 2021

www.commbank.co.id diakses pada 28 Juli 2021

www.bankfama.co.id diakses pada $28 \mathrm{Juli}$ 2021

www.bankmuamalat.co.id diakses pada 28 Juli 2021

www.ir-bankbsi.com diakses pada 28 Juli 2021

www.bnisyariah.co.id diakses pada $28 \mathrm{Juli}$ 2021

www.megasyariah.co.id diakses pada 28 Juli 2021

www.syariahbukopin.co.id diakses pada 28 Juli 2021 